\title{
Job insecurity and its association with health among employees in the Taiwanese general population
}

\author{
Yawen Cheng ${ }^{\mathrm{a}, *}$, Chun-Wan Chen ${ }^{\mathrm{b}}$, Chiou-Jong Chen ${ }^{\mathrm{b}}$, Tung-liang Chiang ${ }^{\mathrm{a}}$ \\ anstitute of Health Policy and Management, College of Public Health, National Taiwan University, 1 Jen-Ai Rd., \\ 1st Sec., Taipei, Taiwan \\ ${ }^{\mathrm{b}}$ Institute of Occupational Safety and Health, Council of Labor Affairs, Taipei, Taiwan
}

Available online 12 January 2005

\begin{abstract}
As employers respond to intensive global competition through the deregulation of labor, job insecurity has become a widespread problem. It has been shown to have significant health impacts in a growing number of workers, but less is known about its social distribution, the mechanisms through which it may act, and the moderating effects of gender, socioeconomic position, and company size. Utilizing data from a national survey of a representative sample of paid employees in Taiwan, we examined the prevalence of job insecurity and its associations with psychosocial work characteristics and health status. A total of 8705 men and 5986 women aged between 25 and 65 years old were studied. Information on perceived job insecurity, industrial and occupational types, psychosocial work characteristics as assessed by the Job Strain model, and various measures of health status were obtained by a self-administered questionnaire. The overall prevalence of job insecurity was high $(50 \%)$. Job insecurity was more prevalent among employees with lower education attainment, in blue-collar and construction workers, those employed in smaller companies, and in older women. Insecure employees also reported lower job control, higher job demands, and poor workplace social support, as compared with those who held secure positions. Regression analyses showed that job insecurity was strongly associated with poor health, even with adjustment of age, job control, job demands, and work place social support. The deleterious effects of job insecurity appeared to be stronger in men than women, in women who held managerial or professional jobs than women in other employment grades, and in those working in larger companies than smaller ones. The findings of this study suggest that perceived job insecurity is an important source of stress, and it is accompanied with adverse psychosocial work conditions and poor health. High-risk groups were identified for further investigation.
\end{abstract}

(C) 2004 Elsevier Ltd. All rights reserved.

Keywords: Job insecurity; Job strain; Health status; Survey; Taiwan

\section{Introduction}

It has been well documented that unemployment is strongly associated with increased mortality, morbidity,

\footnotetext{
*Corresponding author. Tel.: + 886223123456 , ext. 8343; fax: +886223215048 .

E-mail address: ycheng@ha.mc.ntu.edu.tw (Y. Cheng).
}

and reduced quality of life (Hamilton, Rroman, Hoffman, \& Renner, 1990; Morris, Cook, \& Shaper, 1994; Bartley, Ferrie, \& Montgomery, 1999). In today's economy when flexibility in the job market has been proposed as a prerequisite for economic efficiency and also as a solution for rising unemployment, the division between unemployment and various forms of marginal employment is becoming blurred, however. Especially in 
countries that have less regulated labor markets, jobs characterized by flexible and temporary work contracts, on piece-work basis, with lower benefit, poor work conditions and reduced job security might become even more prevalent. Some studies have suggested that prolonged exposure to job insecurity and threat of job loss might be even more harmful than the experience of unemployment itself (Arnetz et al., 1991; Heaney, Israel, \& House, 1994; Aronsson, 1999).

We synthesized existing literature and proposed a causal model linking job insecurity to health, as illustrated in Fig. 1 (Fenwick \& Tausig, 1994; McDonough, 2000). The deleterious effects of insecure employment may result from anxiety of potential job loss, as well as high levels of exposure to various types of work hazards, including heavier workloads, loss of job control, and decreased workplace social support (Benach, Amable, Muntaner, \& Benavides, 2002; Benach, Benavides, Platt, Diez-Roux, \& Muntaner, 2000; Benach, Muntaner, Benavides, Amable, \& Jodar, 2002). There has been growing interest in recent years in studying the impacts of insecure employment on health. Most initial evidences originated from longitudinal studies of workplace closures or downsizing (Jenkins, MacDonald, Murray, \& Strathdee, 1982; Joelson \& Wahlquist, 1987; Mattiasson, Lindgarde, Nilsson, \& Theorell, 1990; Arnetz et al., 1991; Ferrie, Shipley, Marmot, Stansfeld, \& Davey Smith, 1995; Ferrie, Shipley, Marmot, Stansfeld, \& Smith, 1998a, b; Ferrie, Shipley, Stansfeld, \& Marmot, 2002). These studies were consistent in showing that the experience of job insecurity before actual job changes increased the risks of mental and physical illnesses. In addition, insecure jobs are also more likely to accompany with inadequate work conditions. It has been shown that organizational restructuring and downsizing resulted in worsening work conditions, including loss of autonomy and selfcontrol, higher work demands with reduced manpower, closer supervision by management, decreased workplace social support, and wage cuts (Kivimaki, Vahtera, Pentti, \& Ferrie, 2000; Kivimaki, Vahtera, Ferrie, Hemingway, \& Pentti, 2001; Denton, Zeytinoglu, Davies, \& Lian, 2002). In several recent cross-sectional surveys, persons who perceived high level of job insecurity were found to have poor health (Domenighetti, D’Avanzo, \& Bisig, 2000; McDonough, 2000), decreased safety motivation, and higher levels of workplace injuries and accidents (Probst, 2000, 2002; Probst \& Brubaker, 2001).

Despite these important findings, some research questions remain to be solved. To our knowledge, there have been few studies attempting to evaluate both the direct psychological impacts of job insecurity and its indirect effects through accompanying structural inequalities in psychosocial work conditions. In addition, most studies up to date have focused on experiences in specific occupations or work organizations; little research have examined the social distribution of job insecurity in a wide spectrum of general working populations and in both genders. Furthermore, while the meaning of job insecurity and available social resources to cope with it may differ across socioeconomic strata and between genders, to what extent the health-related impacts of job insecurity may be modified according to these variables has not been systematically evaluated.

Data from a large-scale national survey conducted in 2001 in a representative sample of Taiwanese employees allows us to address these issues. Especially, from an international aspect, findings from Taiwan may contribute in enriching job insecurity literature, because up until now studies concerning the health impacts of job insecurity have come almost exclusively from European countries and the United States. There have been few studies from less developed countries, and it is even rare to find studies conducted in Chinese populations.

Known as one of the Asia's "four little tigers", Taiwan experienced rapid industrialization and significant economic growth since the 1950s. During the period from the 1950s to the mid-1990s, Taiwan attained an average annual growth in the gross national product (GNP) of $8.6 \%$ and kept unemployment rates well below 2\%. Since the mid-1990s, however, Taiwan's economy began to decline as consequences of intensified global competition. In 2001, the annual economic growth rate even dropped to a historical low of $-2.2 \%$, and the unemployment rate soared up to $4.7 \%$. The main reason for unemployment had shifted

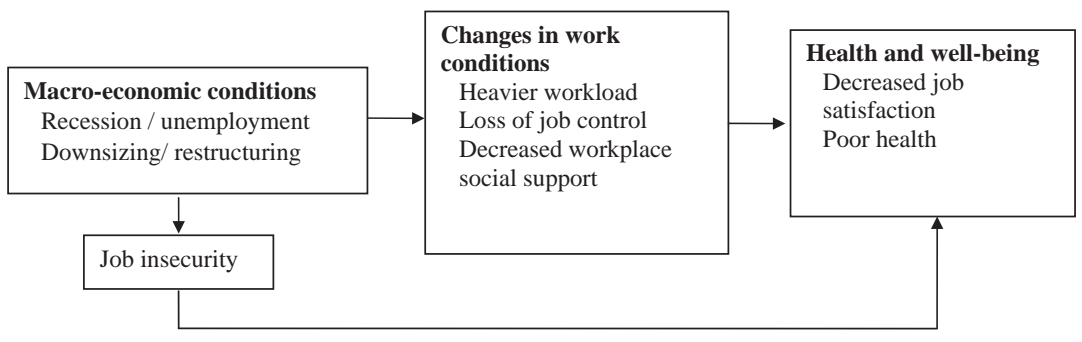

Fig. 1. Pathways linking job insecurity to Health. 
from voluntary job resignation to involuntary job loss due to downsizing or company closures since the mid1990s (data source: Yearbook of Labor Statistics, Council of Labor Affairs, 2001; Yearbook of Directorate-General of Budget, Accounting and Statistics, 2001, Executive Yuan, Taiwan).

Compared to many European countries, Taiwan's unemployment rates might not be considered high, yet these figures underestimate the impacts of associated problems, such as a growing proportion of contingent work, underemployment, and worsening labor conditions. Especially, Taiwan's workforce has already been quite flexible because of the dominance of small-size enterprises of its economy. As a newly developed country, Taiwan has invested very little to social protection for workers against the threat of job loss. The labor force in Taiwan is largely not unionized and lacking in collective power. This could be explained by the long history of martial law and a prevailing ideology that values entrepreneurship, competition, and individual successes. Lay-offs without early notice and financial compensation happen commonly, and unemployment is generally regarded as a personal failure rather than a social problem. We anticipated that the prevalence of job insecurity might be high in Taiwan, and its toll on workers' health and wellbeing might be enormous.

There were three objectives in this study. First, we examined the prevalence and social distribution of job insecurity across different demographic and work categories. Secondly, the effects of job insecurity on workers' job satisfaction and health status were examined and compared before and after controlling for the three main components of the Job Strain Model, namely job control, job demands, and work-place social support. The Job Strain Model conceptualized by Karasek and Theorell postulates that a combination of high demands, low control at work, and poor workplace social support leads to psychological strain and stressrelated illnesses (Karasek \& Theorell, 1990). This model has been the central piece of the job stress research and has been shown to predict health problems related to job stress (Karasek, Baker, Marxer, Ahlbom, \& Theorell, 1981; Schnall, Landsbergis, \& Baker, 1994; Hurrell, Nelson, \& Simmons, 1998; Karasek et al., 1998; Cheng, Kawachi, Coakley, Schwartz, \& Colditz, 2000; Levi et al., 2000). Lastly, we tested the hypotheses if the health effects of job insecurity might vary by socioeconomic status and might be stronger for men than for women, taking into account of the greater social expectation of work role for men than for women (Kristensen, Borg, \& Hannerz, 2002). We were also interested in exploring the moderating effects of company size on the associations between job insecurity and health outcomes, because of the dominance of small-size enterprises in Taiwan's economy and also for the consideration that the size of a company might have great influence on the employees' expectations on job stability.

\section{Methods}

\section{Participants and procedures}

The Institute of Occupational Safety and Health of Taiwan had conducted nation-wide surveys concerning occupational health every $3-5$ years since 1988 . For the survey conducted in September 2001, a representative sample of paid employees was selected by a two-stage sampling scheme. In the first stage, all of the 7365 districts and villages were grouped into 24 strata according to their levels of urbanization. Districts ("Li") in urban areas and villages ("Cwen") in rural areas are the basic administration units in Taiwan, each consisting of several hundreds to several thousands of residents. Within each stratum, districts and villages were first ordered by the size of encompassing households, and a random sample was selected by a systematic sampling method with a random start and a fixed interval. The number to be sampled from a specific stratum was determined by the total numbers of districts and villages in that stratum. A total of 502 districts and villages were sampled in the first stage. In the second stage, households were firstly ordered by addresses within each district or village, and a sample was drawn by systematic sampling method with a random start and fixed interval. Likewise, the number of households to be sampled from a specific district or village was proportional to the total numbers of households in that district or village. A total of 18,600 households were selected in the second stage. Because random sampling was applied in both stages, the representativeness of the sample was ensured.

In these sampled households, 21,066 residents currently working as paid employees at the time of this survey were identified. Among them, 17,272 (82\%) participated in this study. We restricted the study population to those aged between 25 and 65 years old, resulting in 14,691 subjects (8705 men and 5986 women) available for analyses.

A standardized self-administered questionnaire was delivered to each sampled household by a trained interviewer, and the purposes of the study were explained in person. Within a week, the same interviewer visited eligible subjects who agreed to participate, and collected the answered questionnaires. Upon the receipt of the questionnaire, the interviewer performed on-site checking to ensure the completeness of the questionnaire and to correct possible errors.

\section{Measures}

The questionnaire was designed to assess multiple dimensions of work conditions, including work patterns, 
physical hazards and psychosocial work characteristics, as well as employees' perceptions of the safety and health problems in the work place. Perceived job insecurity was assessed by a single item adopted from Karasek's Job Content Questionnaire (JCQ), asking participants whether or not they agree the statement "My job is secure". The response was recorded on a four-point scale, ranging from strongly agree, agree, disagree, and strongly disagree. For analysis in this study, we dichotomized the response into "agree" vs. "disagree". In addition, participants were asked to provide information on their age, sex, education level, job title and occupational grade, type of industry, years of employment in the current company, and total work hours over the week before the survey. They were also asked whether or not they were civil servants working in governments; employees in non-governmental sectors were asked to indicate the size of their companies.

For the assessment of psychosocial work characteristics, the JCQ based on Karasek's demand-control-support model, also known as the Job Strain model, was adopted. Detailed information with regard to the content and the psychometric properties of the Chinese version of JCQ (C-JCQ) can be found elsewhere (Cheng, Luh, \& Guo, 2003). In short, the questionnaire consisted of 22 core items for assessment of three major JCQ scales, namely, job control, psychological demands, and workplace social support. The job control scale is the sum of 2 subscales: skill discretion, measured by six items, and decision authority, measured by three items. The psychological demands scale is measured by five items. The work-related social support scale is the sum of two subscales: support from supervisors and support from co-workers, both measured by four items. Cronbach's alpha coefficients were all above 0.80 for all of the C-JCQ sub-scales in this population, except for psychological demands subscale (0.45). We also adopted five items from the JCQ for assessment of job satisfaction. A sum of weighted item scores was calculated, with a range from 0 (completely unsatisfied) to 100 (completely satisfied).

Self-rated health status over the past month before the survey was assessed by three sub-scales of the standard Taiwanese version of the Short-Form 36 (SF-36): mental health was assessed by five items for both positive and negative emotional states; vitality was measured by four items for perceived level of energy and fatigue; and general health was assessed by five items for self-rated health conditions. Subjects with missing data on more than half of the items in a SF-36 sub-scale were considered incomplete and were excluded from final analyses. For remaining subjects with some missing data on SF-36 items, an average score was imputed based on all the other items they responded on the sub-scale (Ware, Snow, Kosinski, \& Gandek, 1993). All scales were transformed to range between 0 (worst health) and 100 (best health).

Participants were asked if they had experienced the following somatic symptoms over the past year: "itchy or irritating skin", "strained eyes", "ringing ears or hearing problems", "stomach ache or peptic ulcers", and "sleep problems". The responses were recorded on 4-point scale (never, seldom, sometimes, and often). For interest of simplicity, these responses were dichotomized (never/seldom vs. sometimes/often) in this study. A separate checklist was designed for assessing musculoskeletal discomfort at various parts of the body, and the responses to all of the checklist items were recorded dichotomously (ever vs. never). A summary measure for musculoskeletal discomfort was derived for analysis in this study.

\section{Statistical analysis}

The prevalence of job insecurity was examined by demographic and employment categories. Psychosocial work conditions and health status of employees with secure verse insecure jobs were compared and the differences were tested by 2 -sample $t$-test or $\chi^{2}$ test. Multivariate linear regression models were applied to examine the effects of job insecurity on continuous health outcomes, with adjustment for job control, job demands, and workplace social support. For dichotomous health outcomes, adjusted relative risks of job insecurity were calculated using a modified Poisson regression approach with robust error variance, taking into consideration that the outcomes of interest might be common (i.e., a prevalence $>10 \%$ ) (McNutt, $\mathrm{Wu}$, Xue, $\&$ Hafner, 2003). Stratified analyses were performed for the assessment of moderating effects of gender, educational level, employment grade, and company size on the associations between job insecurity and health outcomes. All statistical analyses were performed using SAS software (Software Release 8.2, SAS Institute Inc., Cary, NC, USA).

\section{Results}

\section{Characteristics of the sample}

The demographic and employment characteristics of the studied sample are summarized in Table 1. The mean (SD) ages for men and women were 39.1 (9.3) and 37.6 (8.7), respectively. Manual low-skilled workers accounted for the $30 \%$ of the male workforce; while in the female workforce non-manual low-skilled workers were the largest group, accounting for $36 \%$. A majority of employees were in the service sectors $(47 \%$ in men and $63 \%$ in women), and up to $55 \%$ of the total 
Table 1

Demographic characteristics and prevalence ratios (95\% confidence intervals, $95 \%$ CI) of job insecurity $(n=14691)$

\begin{tabular}{|c|c|c|c|c|c|c|}
\hline \multirow[t]{2}{*}{ Variable } & \multicolumn{3}{|l|}{ Men } & \multicolumn{3}{|l|}{ Women } \\
\hline & $n(\%)$ & $\begin{array}{l}\text { Prevalence of job } \\
\text { insecurity }(\%)\end{array}$ & $\begin{array}{l}\text { Prevalence ratio } \\
(95 \% \mathrm{CI})\end{array}$ & $n(\%)$ & $\begin{array}{l}\text { Prevalence of job } \\
\text { insecurity }(\%)\end{array}$ & $\begin{array}{l}\text { Prevalence ratio } \\
(95 \% \mathrm{CI})\end{array}$ \\
\hline Total & $8705(59.3)$ & 49.0 & & $5986(40.7)$ & 51.1 & \\
\hline \multicolumn{7}{|l|}{ Age (years) } \\
\hline $25 \sim 34$ & $3178(36.5)$ & 50.2 & 1 & $2460(41.1)$ & 49.4 & 1 \\
\hline $35 \sim 44$ & $3008(34.6)$ & 50.7 & $1.01(0.94,1.09)$ & $2172(36.3)$ & 52.0 & $1.05(0.97,1.14)$ \\
\hline $45 \sim 54$ & $1970(22.6)$ & 46.7 & $0.93(0.86,1.01)$ & $1139(19.0)$ & 51.2 & $1.04(0.94,1.14)$ \\
\hline $55 \sim 65$ & $545(6.3)$ & 41.2 & $0.82 *(0.72,0.95)$ & $213(3.6)$ & 59.6 & $1.25^{*}(1.00,1.45)$ \\
\hline \multicolumn{7}{|l|}{ Education (years) } \\
\hline Primary or below $(\leqslant 6)$ & $1045(12.0)$ & 62.2 & 1 & $916(15.3)$ & 68.3 & 1 \\
\hline Junior school (7〜9) & $1670(19.2)$ & 60.1 & $0.97(0.87,1.07)$ & $802(13.4)$ & 61.0 & $0.89(0.79,1.01)$ \\
\hline High school (10 12) & $2968(34.1)$ & 51.0 & $0.82^{* *}(0.75,0.90)$ & $2110(35.2)$ & 53.8 & $0.79 * *(0.72,0.87)$ \\
\hline College (13 16) & $2691(30.9)$ & 37.8 & $0.61 * *(0.55,0.67)$ & $2031(33.9)$ & 37.9 & $0.56^{* *}(0.50,0.62)$ \\
\hline Graduate $(\geqslant 17)$ & $327(3.8)$ & 24.2 & $0.39^{* *}(0.31,0.49)$ & $125(2.1)$ & 28.8 & $0.42 * *(0.30,0.59)$ \\
\hline \multicolumn{7}{|l|}{ Employment grade } \\
\hline G6: Manual low skilled & $2565(29.5)$ & 55.0 & 1 & $1616(27.0)$ & 65.5 & 1 \\
\hline G5: Manual skilled & $1866(21.4)$ & 65.0 & $1.18^{* *}(1.09,1.27)$ & $197(3.3)$ & 71.6 & $1.09(0.92,1.30)$ \\
\hline G4: Non-manual low skilled & $1166(13.4)$ & 42.0 & $0.76^{* *}(0.69,0.85)$ & $2168(36.2)$ & 50.6 & $0.77 * *(0.71,0.84)$ \\
\hline G3: Non-manual skilled & $1994(22.9)$ & 41.1 & $0.75^{* *}(0.69,0.81)$ & $1260(21.0)$ & 46.0 & $0.70 * *(0.63,0.78)$ \\
\hline G2: Professional & $725(8.3)$ & 23.9 & $0.43^{* *}(0.37,0.51)$ & $669(11.2)$ & 23.7 & $0.36^{* *}(0.31,0.43)$ \\
\hline G1: Administrator/manager & $385(4.4)$ & 45.8 & $0.74 * *(0.63,0.87)$ & $74(1.2)$ & 28.4 & $0.43^{* *}(0.28,0.67)$ \\
\hline \multicolumn{7}{|l|}{ Industry } \\
\hline Manufacturing & $3074(35.3)$ & 50.5 & 1 & 1949 (32.6) & 58.5 & 1 \\
\hline Construction & $1361(15.6)$ & 65.8 & $1.30 * *(1.20,1.41)$ & $160(2.7)$ & 65.6 & $1.12(0.92,1.37)$ \\
\hline Service & $4073(46.8)$ & 42.0 & $0.83^{* *}(0.78,0.89)$ & $3775(63.1)$ & 46.0 & $0.79 * *(0.73,0.85)$ \\
\hline \multicolumn{7}{|l|}{ Company size } \\
\hline Government & $1685(19.4)$ & 23.7 & 1 & $1146(19.1)$ & 31.0 & 1 \\
\hline$<10$ & $2569(29.5)$ & 61.5 & $2.60 * *(2.33,2.90)$ & $1602(26.8)$ & 59.6 & $1.92 * *(1.70,2.17)$ \\
\hline $10 \sim<50$ & $2340(26.9)$ & 55.9 & $2.36^{* *}(2.11,2.64)$ & $1656(27.7)$ & 54.1 & $1.74 * *(1.54,1.97)$ \\
\hline $50 \sim<100$ & $588(6.8)$ & 50.8 & $2.14 * *(1.85,2.49)$ & $466(7.8)$ & 56.9 & $1.84 * *(1.57,2.15)$ \\
\hline $100 \sim<500$ & $972(11.2)$ & 45.3 & $1.91 * *(1.67,2.19)$ & $739(12.3)$ & 55.9 & $1.80 * *(1.57,2.08)$ \\
\hline $500+$ & $547(6.3)$ & 43.2 & $1.82 * *(1.55,2.14)$ & $375(6.2)$ & 46.1 & $1.49 * *(1.25,1.79)$ \\
\hline
\end{tabular}

$*: p<0.05, * *: p<0.01$ 
participants was employed in companies with fewer than 50 employees.

\section{Prevalence and social patterning of job insecurity}

Distributions of employees who perceived their job insecure as well as the prevalence ratios of job insecurity and their $95 \%$ confidence intervals by demographic and employment characteristics are also presented in Table 1. Overall, $49 \%$ of men and $51 \%$ of women reported their job insecure. The level of job insecurity decreased by age in men, but increased by age in women. For both men and women, higher levels of job insecurity were found in groups with lower educational attainment and lower occupational grades, and professionals were found to have the lowest levels of job insecurity. With regard to industrial sector, construction workers and those employed in smaller companies reported higher levels of job insecurity. Government's employees had the lowest level of job insecurity as compared to employees in nongovernmental sectors.

\section{Comparisons of secure and insecure jobs in work characteristics and employees' health}

Table 2 shows the comparisons in psychosocial work conditions and health status between employees with and without secure jobs. For both men and women, higher job insecurity was associated with lower levels of skill discretion, decision authority, and social support from supervisor and coworkers. Insecure employees also reported heavier job demands in both sexes, and slightly longer work hours per week in men. With regard to health status, job insecurity was associated with significantly lower levels of mental health, vitality, and general health, increased risks of various health complaints, as well as lower level of job satisfaction.

\section{Health status in association with job insecurity}

As shown in Tables 3 and 4, men and women who perceived their jobs less secure had significantly poor health and lower job satisfaction as compared to

Table 2

Psychosocial work characteristics and health status in subjects with secure vs. insecure jobs

\begin{tabular}{|c|c|c|c|c|c|c|}
\hline \multirow[t]{2}{*}{ Variable $^{\mathrm{a}}$} & \multicolumn{3}{|l|}{ Men } & \multicolumn{3}{|l|}{ Women } \\
\hline & Secure $(n=4264)$ & Insecure $(n=4435)$ & $p$ & Secure $(n=3051)$ & Insecure $(n=2926)$ & $p$ \\
\hline \multicolumn{7}{|c|}{ Psychosocial work characteristics: Mean (SD) } \\
\hline Skill discretion & $33.0(4.8)$ & $30.4(5.2)$ & $* *$ & $31.8(4.6)$ & $29.1(5.1)$ & $* *$ \\
\hline Decision authority & $33.8(5.7)$ & $30.7(6.0)$ & $* *$ & $33.0(5.6)$ & $29.6(6.1)$ & $* *$ \\
\hline Demands & $30.3(3.5)$ & $30.9(3.7)$ & $* *$ & $30.5(3.5)$ & $31.1(3.9)$ & $* *$ \\
\hline Supervisor support & $11.5(1.8)$ & $9.6(2.2)$ & $* *$ & $11.3(1.7)$ & $9.7(2.1)$ & $* *$ \\
\hline Coworker support & $12.2(1.3)$ & $11.4(1.7)$ & $* *$ & $12.2(1.3)$ & $11.5(1.7)$ & $* *$ \\
\hline Work hours (hr/week) & $43.2(8.1)$ & $42.5(10.7)$ & $* *$ & $42.2(8.3)$ & $42.6(9.7)$ & ns \\
\hline \multicolumn{7}{|l|}{ SF-36 health status: Mean (SD) } \\
\hline Mental health & $66.3(12.9)$ & $60.1(13.2)$ & $* *$ & $64.9(13.2)$ & $59.7(13.1)$ & $* *$ \\
\hline Vitality & $65.1(15.6)$ & $57.3(15.4)$ & $* *$ & $61.4(16.2)$ & $55.3(15.7)$ & $* *$ \\
\hline General health & $74.0(17.5)$ & $67.8(17.6)$ & $* *$ & $71.0(17.6)$ & $64.7(17.6)$ & $* *$ \\
\hline Job satisfaction: Mean (SD) & $65.4(14.8)$ & $50.5(15.1)$ & $* *$ & $65.6(15.2)$ & $53.1(14.4)$ & $* *$ \\
\hline \multicolumn{7}{|c|}{ Percentage of employees who had the following somatic symptoms over the past year:\% } \\
\hline Itchy/irritating skins ${ }^{b}$ & $9.3 \%$ & $12.2 \%$ & $* *$ & $10.9 \%$ & $10.8 \%$ & ns \\
\hline Strained eyes ${ }^{\mathrm{b}}$ & $11.3 \%$ & $15.0 \%$ & $* *$ & $16.7 \%$ & $18.4 \%$ & ns \\
\hline Ringing ears/hearing problems ${ }^{\mathrm{b}}$ & $6.2 \%$ & $8.0 \%$ & $* *$ & $5.4 \%$ & $6.7 \%$ & $*$ \\
\hline Stomach ache/ulcers ${ }^{\mathrm{b}}$ & $12.0 \%$ & $14.7 \%$ & $* *$ & $13.8 \%$ & $15.4 \%$ & ns \\
\hline Sleep problems ${ }^{\mathrm{b}}$ & $15.9 \%$ & $20.4 \%$ & $* *$ & $18.8 \%$ & $23.8 \%$ & $* *$ \\
\hline Musculoskeletal discomfort ${ }^{\mathrm{c}}$ & $52.4 \%$ & $62.3 \%$ & $* *$ & $64.3 \%$ & $69.3 \%$ & $* *$ \\
\hline Symptom score $^{\mathrm{d}} \geqq 3$ : & $12.6 \%$ & $17.3 \%$ & $* *$ & $16.0 \%$ & $18.6 \%$ & $* *$ \\
\hline
\end{tabular}

$*: p<0.05, * *: p<0.01$

ns: non-significant.

"A high value indicates a high level of the concept being measured. For example, a high value on the "coworker support" means strong social support from coworkers; while a high value on "demands" indicates heavy job demands.

bPercentage of "often/sometimes" vs. "never/seldom".

'Percentage of "ever" vs. "never".

${ }^{\mathrm{d}}$ Symptom score is sum of positive responses to the six symptoms listed above. 
employees who held more secure positions, when adjusting only for age in the regression models (baseline models, i.e., Model 1). The main effects of education were also examined, and as expected, there were strong associations between higher education level and better health in both men and women (data not shown). The beta coefficients of job insecurity changed little, however, when adjusting for education in the regression models. For interest of simplicity, only age-adjusted models were presented.

When further controlling for the three main components from the Job Strain model, i.e., job control, job demands, and workplace social support, the magnitudes of effects of job insecurity attenuated markedly but remained significant. The degree of attenuation in the differences of SF-36 health status ranged from $38 \%$ to $57 \%$.

Overall, the effects of job insecurity appeared to be stronger in men than in women (Tables 3 and 4). When analyses were stratified by educational level, the effects of job insecurity on health did not seem to vary in a systematic pattern (data not shown). However, when stratified by employment grade, women who held managerial or professional jobs seemed to be more severely affected by job insecurity than women in other employment grades, while there was no consistent pattern in men (Tables 3 and 4).

For company size, the results of stratified regression analyses suggested that the effects of job insecurity were more apparent among non-governmental employees who worked in lager companies with a size of workforce of 50 or above, as compared to employees of smaller business and government's employees (Tables 3 and 4). These findings were not conclusive however, because cross-table examinations indicated that the three groups were not comparable in terms of their demographic and industrial structures (data not shown). Government's employees worked predominantly in the service sectors ( $84 \%$ in men and $97 \%$ in women), had a greatest proportion of people with a college degree or above ( $55 \%$ in men and $65 \%$ in women), and were mostly white-collar workers. Employees in larger companies were dominated by manufacturing workers $(65 \%$ in men and $58 \%$ in women), while for employees of smaller business, there were more construction workers and more people with lower socioeconomic status as compared to the other two groups.

\section{Discussion}

The results of this study indicated that, $50 \%$ of employees in Taiwan perceived their jobs insecure. The prevalence of job insecurity found in this study was relatively high, as compared to other studies that used the same JCQ item with the same response scale. For example, a national survey of 1319 working men and women conducted in 1990 in the United States found a prevalence of job insecurity of $16 \%$ (Lerner, Levine, Malspeis, \& D'Agostino, 1994); and the Nurses Health Study, a cohort of female registered nurses in the United States, reported a prevalence of job insecurity of $17.6 \%$ in 1992 (Lee, Colditz, Berkman, \& Kawachi, 2004).

The overall prevalence of job insecurity might even be higher in Taiwan, when taking into account a sizable proportion of workforce that was not included in this survey. In 2001, paid employees accounted for $72 \%$ of Taiwan's total workforce, while the other $5.5 \%, 16.5 \%$ and $7 \%$ were employers, self-employed workers, and unpaid family workers, respectively (data source: Yearbook of Directorate-General of Budget, Accounting and Statistics, 2001, Executive Yuan, Taiwan). Taiwanese employers are mostly owners of small businesses which had short life cycles, thus they might confront a great deal of stress from intensive market competition. Although the self-employed and unpaid family workers might consist of heterogeneous groups and their work conditions might vary considerably according to underlying forces and motives, these groups are likely to be on the margin of labor market, competing to survive on their own.

As expected, employees with lower socioeconomic status, blue-collar and construction workers, and those working in smaller companies were found to be at greater risk of exposure to insecure employment, and professionals and government's employees were least likely to have insecure jobs. The gradient of decreasing job insecurity by company size was especially apparent for men than for women. These findings suggested that previous studies conducted in workers of large-size companies, professionals or civil servants might have greatly underestimated the scope of job insecurity problem in the general public.

Interestingly, while the level of job insecurity decreased by age in men, it increased in women. A recent survey among Danish employees also reported a highest prevalence of job insecurity among women with low socioeconomic status (Kristensen et al., 2002). In Taiwan, women's labor participation rate is low $(45.9 \%$ in 2001) as compared to many western countries. Our findings indicated that, in contrast to male employees who tended to gain seniority and more secure positions when they aged, available jobs for older women who had to remain working were usually temporary and insecure.

In consistent with several previous cross-sectional surveys (Domenighetti et al., 2000; McDonough, 2000; Probst, 2002; Probst \& Brubaker, 2001), our study found that employees who perceived their job insecure exhibited poor health and lower level of job satisfaction. The results of our regression analyses suggested that job insecurity itself was an important source of job stress 
Table 3

Multivariate-adjusted beta coefficients and risk ratios of job insecurity on health outcomes in men

\begin{tabular}{|c|c|c|c|c|c|c|c|c|}
\hline & \multirow{3}{*}{$\begin{array}{l}\text { Model }(1)^{\mathrm{a}} \\
\text { All } \\
(n=8705)\end{array}$} & \multirow{3}{*}{$\begin{array}{l}\text { Model }(2)^{\mathrm{b}} \\
\text { All } \\
(n=8705)\end{array}$} & \multicolumn{3}{|l|}{ Model $(2)^{b}$} & \multicolumn{3}{|l|}{ Model $(2)^{\mathrm{b}}$} \\
\hline & & & \multicolumn{3}{|c|}{ Stratified by employment grade } & \multicolumn{3}{|c|}{ Stratified by company size } \\
\hline & & & $\mathrm{G} 1 / 2(n=1110)$ & $\mathrm{G} 3 / 4(n=3160)$ & $\mathrm{G} 5 / 6(n=4435)$ & $<50(n=4911)$ & $\geqslant 50(n=2109)$ & Government $(n=1685)$ \\
\hline $\begin{array}{l}\text { Continuous outcome } \\
\text { Mental health }\end{array}$ & $\begin{array}{l}\beta(95 \% C I) \\
-6.09^{* *} \\
(-6.65,-5.54)\end{array}$ & $\begin{array}{l}\beta(95 \% C I) \\
-3.23 * * \\
(-3.83,-2.63)\end{array}$ & $\begin{array}{l}\beta(95 \% C I) \\
-5.35^{* *} \\
(-7.03,-3.67)\end{array}$ & $\begin{array}{l}\beta(95 \% C I) \\
-3.43^{* *} \\
(-4.46,-2.40)\end{array}$ & $\begin{array}{l}\beta(95 \% C I) \\
-4.16^{* *} \\
(-5.01,-3.31)\end{array}$ & $\begin{array}{l}\beta(95 \% C I) \\
-2.90^{* *} \\
(-3.72,-2.08)\end{array}$ & $\begin{array}{l}\beta\left(95^{\circ} \% C I\right) \\
-3.45^{* *} \\
(-4.67,-2.23)\end{array}$ & $\begin{array}{l}\beta(95 \% C I) \\
-2.67 * * \\
(-4.15,-1.19)\end{array}$ \\
\hline Vitality & $\begin{array}{l}-7.75^{* *} \\
(-8.40,-7.09)\end{array}$ & $\begin{array}{l}-4.14^{* *} \\
(-4.84,-3.44)\end{array}$ & $\begin{array}{l}-4.99 * * \\
(-7.03,-2.96)\end{array}$ & $\begin{array}{l}-4.04^{* *} \\
(-5.22,-2.86)\end{array}$ & $\begin{array}{l}-5.43^{* *} \\
(-6.43,-4.44)\end{array}$ & $\begin{array}{l}-3.57^{* *} \\
(-4.52,-2.63)\end{array}$ & $\begin{array}{l}-4.60^{* *} \\
(-6.04,-3.17)\end{array}$ & $\begin{array}{l}-3.11^{* *} \\
(-4.85,-1.38)\end{array}$ \\
\hline General health & $\begin{array}{l}-6.41^{* *} \\
(-7.14,-5.67)\end{array}$ & $\begin{array}{l}-3.73 * * \\
(-4.55,-2.92)\end{array}$ & $\begin{array}{l}-4.89 * * \\
(-7.17,-2.62)\end{array}$ & $\begin{array}{l}-3.46^{* *} \\
(-4.80,-2.12)\end{array}$ & $\begin{array}{l}-4.73^{* *} \\
(-5.90,-3.57)\end{array}$ & $\begin{array}{l}-3.49 * * \\
(-4.60,-2.38)\end{array}$ & $\begin{array}{l}-4.58^{* *} \\
(-6.23,-2.93)\end{array}$ & $\begin{array}{l}-3.62 * * \\
(-5.65,-1.59)\end{array}$ \\
\hline Job satisfaction & $\begin{array}{l}-14.71^{* *} \\
(-15.34,-14.08)\end{array}$ & $\begin{array}{l}-8.56^{* *} \\
(-9.20,-7.92)\end{array}$ & $\begin{array}{l}-9.48 * * \\
(-11.34,-7.62)\end{array}$ & $\begin{array}{l}-8.97 * * \\
(-10.05,-7.89)\end{array}$ & $\begin{array}{l}-9.16^{* *} \\
(-10.07,-8.25)\end{array}$ & $\begin{array}{l}-6.93^{* *} \\
(-7.79,-6.08)\end{array}$ & $\begin{array}{l}-8.03^{* *} \\
(-9.33,-6.73)\end{array}$ & $\begin{array}{l}-6.98^{* *} \\
(-8.50,-5.45)\end{array}$ \\
\hline $\begin{array}{l}\text { Dichotomous outcome } \\
\text { Symptom score } \geqslant 3\end{array}$ & $\begin{array}{l}R R(95 \% C I) \\
1.19^{* *} \\
(1.12,1.28)\end{array}$ & $\begin{array}{l}R R(95 \% C I) \\
1.15^{* *} \\
(1.07,1.24)\end{array}$ & $\begin{array}{l}R R(95 \% C I) \\
1.19 \\
(0.98,1.46)\end{array}$ & $\begin{array}{l}R R(95 \% C I) \\
1.14^{*} \\
(1.07,1.29)\end{array}$ & $\begin{array}{l}R R(95 \% C I) \\
1.15^{* *} \\
(1.04,1.28)\end{array}$ & $\begin{array}{l}R R(95 \% C I) \\
1.15^{* *} \\
(1.04,1.28)\end{array}$ & $\begin{array}{l}R R(95 \% C I) \\
1.21^{* *} \\
(1.05,1.40)\end{array}$ & $\begin{array}{l}R R(95 \% C I) \\
1.21^{*} \\
(1.02,1.44)\end{array}$ \\
\hline
\end{tabular}

$*: p<0.05, * *: p<0.01$.

${ }^{a}$ Model (1) - adjusting for age.

${ }^{\mathrm{b}}$ Model (2)-further adjusting for job control, job demands, and work-place social support. 
Table 4

Multivariate-adjusted beta coefficients and risk ratios of job insecurity on health outcomes in women

\begin{tabular}{|c|c|c|c|c|c|c|c|c|}
\hline & \multirow{3}{*}{$\begin{array}{l}\text { Model }(1)^{\mathrm{a}} \\
\text { All } \\
(n=5986)\end{array}$} & \multirow{3}{*}{$\begin{array}{l}\text { Model }(2)^{\mathrm{b}} \\
\text { All } \\
(n=5986)\end{array}$} & \multicolumn{3}{|l|}{$\operatorname{Model}(2)^{b}$} & \multicolumn{3}{|l|}{$\operatorname{Model}(2)^{\mathrm{b}}$} \\
\hline & & & \multicolumn{3}{|c|}{ Stratified by employment grade } & \multicolumn{3}{|c|}{ Stratified by company size } \\
\hline & & & $\mathrm{G} 1 / 2(n=744)$ & $\mathrm{G} 3 / 4(n=3428)$ & $\mathrm{G} 5 / 6(n=1814)$ & $<50(n=4911)$ & $\geqslant 50(n=2109)$ & Government $(n=1685)$ \\
\hline $\begin{array}{l}\text { Continuous outcome } \\
\text { Mental health }\end{array}$ & $\begin{array}{l}\beta(95 \% C I) \\
-5.20^{* *} \\
(-5.88,-4.53)\end{array}$ & $\begin{array}{l}\beta(95 \% C I) \\
-2.74 * * \\
(-3.46,-2.03)\end{array}$ & $\begin{array}{l}\beta\left(95^{\circ} \mathrm{CI}\right) \\
-4.50^{* *} \\
(-6.69,-2.31)\end{array}$ & $\begin{array}{l}\beta(95 \% C I) \\
-3.02 * * \\
(-3.97,-2.08)\end{array}$ & $\begin{array}{l}\beta(95 \% C I) \\
-3.06^{* *} \\
(-4.41,-1.71)\end{array}$ & $\begin{array}{l}\beta(95 \% C I) \\
-2.41^{* *} \\
(-3.41,-1.42)\end{array}$ & $\begin{array}{l}\beta\left(95^{\circ} \text { CI }\right) \\
-3.29^{* *} \\
(-4.64,-1.95)\end{array}$ & $\begin{array}{l}\beta\left(95^{\circ} C I\right) \\
-2.25^{*} \\
(-3.97,-0.52)\end{array}$ \\
\hline Vitality & $\begin{array}{l}-6.11^{* *} \\
(-6.92,-5.30)\end{array}$ & $\begin{array}{l}-2.63^{* *} \\
(-3.49,-1.78)\end{array}$ & $\begin{array}{l}-5.07^{* *} \\
(-7.83,-2.30)\end{array}$ & $\begin{array}{l}-2.63^{* *} \\
(-3.75,-1.52)\end{array}$ & $\begin{array}{l}-2.82^{* *} \\
(-4.44,-1.20)\end{array}$ & $\begin{array}{l}-2.26^{* *} \\
(-3.44,-1.09)\end{array}$ & $\begin{array}{l}-3.24^{* *} \\
(-4.87,-1.60)\end{array}$ & $\begin{array}{l}-2.48^{*} \\
(-4.55,-0.40)\end{array}$ \\
\hline General health & $\begin{array}{l}-6.24 * * \\
(-7.13,-5.36)\end{array}$ & $\begin{array}{l}-3.85^{* *} \\
(-4.81,-2.89)\end{array}$ & $\begin{array}{l}-7.92^{* *} \\
(-11.07,-4.77)\end{array}$ & $\begin{array}{l}-4.03^{* *} \\
(-5.27,-2.80)\end{array}$ & $\begin{array}{l}-3.52^{* *} \\
(-5.35,-1.68)\end{array}$ & $\begin{array}{l}-3.55^{* *} \\
(-4.88,-2.23)\end{array}$ & $\begin{array}{l}-5.04^{* *} \\
(-6.90,-3.20)\end{array}$ & $\begin{array}{l}-2.90^{*} \\
(-5.20,-0.60)\end{array}$ \\
\hline Job satisfaction & $\begin{array}{l}-12.51^{* *} \\
(-13.26,-11.76)\end{array}$ & $\begin{array}{l}-7.12^{* *} \\
(-7.88,-6.36)\end{array}$ & $\begin{array}{l}-9.50^{* *} \\
(-11.75,-7.26)\end{array}$ & $\begin{array}{l}-6.76^{* *} \\
(-7.75,-5.77)\end{array}$ & $\begin{array}{l}-6.21^{* *} \\
(-7.64,-4.78)\end{array}$ & $\begin{array}{l}-5.73^{* *} \\
(-6.76,-4.71)\end{array}$ & $\begin{array}{l}-6.68^{* *} \\
(-8.15,-5.22)\end{array}$ & $\begin{array}{l}-7.53 * * \\
(-9.34,-5.73)\end{array}$ \\
\hline Dichotomous outcome & $R R(95 \% C I)$ & $R R(95 \% C I)$ & $R R(95 \% C I)$ & $R R(95 \% C I)$ & $R R(95 \% C I)$ & $R R(95 \% C I)$ & $R R(95 \% C I)$ & $R R(95 \% C I)$ \\
\hline Symptom score $\geqslant 3$ & $\begin{array}{l}1.06 \\
(0.98,1.14)\end{array}$ & $\begin{array}{l}1.05 \\
(0.96,1.14)\end{array}$ & $\begin{array}{l}1.08 \\
(0.85,1.37)\end{array}$ & $\begin{array}{l}1.06 \\
(0.95,1.47)\end{array}$ & $\begin{array}{l}1.05 \\
(0.90,1.24)\end{array}$ & $\begin{array}{l}1.04 \\
(0.92,1.17)\end{array}$ & $\begin{array}{l}1.11 \\
(0.96,1.30)\end{array}$ & $\begin{array}{l}1.12 \\
(0.93,1.34)\end{array}$ \\
\hline
\end{tabular}

${ }^{\mathrm{a}}$ Model (1)-adjusting for age.

${ }^{\mathrm{b}}$ Model (2) - further adjusting for job control, job demands, and work-place social support. 
even with adjustment of exposures to other adverse psychosocial work conditions, namely lower job control, higher job demands, and poor social support at work. Our findings were in consistence with other studies (Arnetz et al., 1991; Jenkins et al., 1982; Mattiasson et al., 1990). For example, in a study of newspaper journalists threatened with redundancy, minor psychiatric symptoms were found elevated, and symptoms diminished following the subsequent withdrawal of notices (Jenkins et al., 1982). In a longitudinal study during the closure of a shipyard, workers threatened with job loss had significantly elevated scores for sleep disturbance, depression, anxiety, and increased level of serum cholesterol than other workers (Mattiasson et al., 1990). A prospective study of blue-collar Swedish workers who experienced job loss showed that psychological stress was most severe during the anticipatory phase of unemployment (Arnetz et al., 1991). Recent studies from the Whitehall II study of British civil servants reported that self-reported health status of employees whose department faced privatization deteriorated significantly during the anticipatory phase of job change (Ferrie et al., 1995; Ferrie et al., 1998a,b).

Insecure jobs were also more likely to accompany with lower job control, higher job demands, and poor workplace social support. These measures of psychosocial work conditions have been found to increase job strain, and hence the risk of ill health (Karasek et al., 1988; Karasek \& Theorell, 1990; Schnall et al., 1994). It can be expected that when a flexible work force is favored by management, employees often encounter deteriorating work conditions, including shrinking size of workforce, increasing workloads, loss in collective power at work, lowering wages, benefits, or promotion opportunities, and increasing tension and conflicts between employers and co-workers.

Although the prevalence of job insecurity was slightly higher in female employees, the deleterious effects of job insecurity appeared to be stronger in male than female employees. This could be explained by a greater expectation of work role for men than for women. Traditionally, part-time and casual jobs that allow the combination of work and family roles are often expected for women, thus job insecurity might have been taken for granted and less likely to be perceived as a threat for women than for men.

A few of recent studies have reported greater psychological health impacts from fear of job loss for the highly educated employees than for the less educated (Domenighetti et al., 2000; Probst, 2000), suggesting that employees who highly invested in their careers were most adversely affected by job insecurity. Nevertheless, one may anticipate an opposite direction, considering the fact that the lower socioeconomic groups might have fewer resources to cope with the threat of unemployment. In the present study, we did not find evidence of moderating effect by education level. Yet, the finding that women who held managerial or professional jobs seemed to be more severely affected deserves further investigation, in spite of a much lower prevalence of job insecurity in this group.

In terms of company size, our findings suggested that the effects of job insecurity were greatest for employees in larger companies. We suspected that insecure employees of larger companies might perceive greater relative deprivation as compared to their more secure colleagues, thus were more vulnerable to psychological stress. It might be also possible that work hazards and available coping resources were more unevenly distributed between secure and insecure workers in larger companies. However, our analyses were exploratory in nature and these findings were inconclusive, because employees in different size of companies were not really comparable in many aspects and there might be potential confounding factors that were not measured in this study.

In conclusion, the results of this study indicate that perceived job insecurity is an important source of stress, and it is associated with both adverse psychosocial work conditions and poor health. The conventional dichotomy of employment versus unemployment tends to underestimate the health impacts of inadequate jobs. Policies and legislation that affect the labor market and work environment should pay attention to the overall quality of the jobs and its consequences to public health.

There are several limitations in this study that should be noticed, however. First, the cross-sectional nature of this study limits the causal interpretation of these findings. One may argue that less healthy people are more likely to be threatened first with job loss, or more likely to be selected into insecure and poor quality jobs. Ill health may be therefore a cause, rather than a consequence of job insecurity. Nevertheless, the findings of our study are still of importance in pointing out susceptible populations. Regardless its causal directions, the links between poor health and inadequate work conditions would result in widening social inequalities, especially in the recent trends of intensive market competition and deregulation of the labor market (Aronsson, 1999; Benach et al., 2002).

Secondly, because job insecurity was subjectively measured in this study, its validity might be questionable. The response to the questionnaire item on job insecurity might reflect merely individual's appraisal rather than a true external threat. One may suspect that the observed associations of higher job insecurity and poor health might have been inflated by confounding effects of individual cognitive response. To evaluate the validity of the single-item question on job insecurity, we correlated the aggregated prevalence rates of perceived job insecurity obtained from this survey with the unemployment rates that were documented by the 23 city and county governments in Taiwan. The correlation 
was moderately high (R-square, 27\%), indicating sufficient validity.

Another limitation concerns of the measures of work hazards. In addition to the three major components of the Job Strain Model that were measured in this study, there must be other important psychosocial work hazards that are also associated with insecure employment, such as physical work hazards, poor safety provision, inadequate wages and welfare, limited career prospects, etc. Future studies should include measures for a more comprehensive assessment of other occupational work hazards.

Lastly, we cannot rule out the possibility that the observed associations might have been biased by other confounders that were not measured in this study. For example, the psychological effects of job insecurity might have been overestimated due to confounding effects of unfavorable health behaviors such as smoking, lack of leisure-time activities and unhealthy dietary patterns, as well as effects of other life stressors such as economic strain and poor living conditions. These factors were more prevalent in people who had insecure jobs. Nevertheless, considering the centrality of work in adult life and the fact that type and quality of work strongly influence personal behaviors and material conditions, it could be argued that these factors might be consequences of insecure employment, thus should not be considered as confounders.

\section{Acknowledgements}

This study was supported by the Institute of Occupational Safety and Health, Council of Labor Affairs, and research grants from the National Science Council (NSC 90-2320-B006-090, NSC91-2320-B006-087), Taiwan. The authors thank three anonymous reviewers for their in-depth review and valuable comments, and Ms. Wanyu Yeh for her assistance with data analyses.

\section{References}

Arnetz, B., Brenner, S., Levi, L., Hjelm, R., Petterson, I., Wasserman, J., et al. (1991). Neuroendocrine and immunological effects of unemployment and job insecurity. Psychotherapy and psychosomatics, 55, 76-80.

Aronsson, G. (1999). Influence of worklife on public health. Scandinavian Journal of Work, Environment and Health, 25(6, special), 597-604.

Bartley, M., Ferrie, J. E., \& Montgomery, S. (1999). Living in a high-unemployment economy: understanding the health consequences. In M. Marmot, \& R. Wilkinson (Eds.), Social determinants of health (pp. 81-104). New York: Oxford University Press.

Benach, J., Amable, M., Muntaner, C., \& Benavides, F. (2002). The consequences of flexible work for health: are we looking at the right place? Journal of Epidemiology and Community Health, 56(6), 405-406.

Benach, J., Benavides, F., Platt, S., Diez-Roux, A., \& Muntaner, C. (2000). The health-damaging potential of new types of flexible employment: a challenge for public health researchers. American Journal of Public Health, 90(8), 1316-1317.

Benach, J., Muntaner, C., Benavides, F., Amable, M., \& Jodar, P. (2002). A new occupational health agenda for a new work environment. Scandinavian Journal of Work, Environment andHealth, 28(3), 191-196.

Cheng, Y., Kawachi, I., Coakley, E., Schwartz, J., \& Colditz, G. (2000). Association between psychosocial work characteristics and health functioning in American women: prospective study. British Medical Journal, 320, 1432-1436.

Cheng, Y., Luh, W.-M., \& Guo, Y.-L. (2003). Reliability and validity of the Chinese version of the Job Content Questionnaire (C-JCQ) in Taiwanese workers. International Journal of Behavioral Medicine, 10(1), 15-30.

Denton, M., Zeytinoglu, I. U., Davies, S., \& Lian, J. (2002). Job stress and job dissatisfaction of home care workers in the context of health care restructuring. International Journal of Health Services, 32(2), 327-357.

Domenighetti, G., D’Avanzo, B., \& Bisig, B. (2000). Health effects of job insecurity among employees in the Swiss general population. International Journal of Health Services, 30(3), 477-490.

Fenwick, R., \& Tausig, M. (1994). The macroeconomic context of job stress. Journal of Health and Social Behavior, 35, 266-282.

Ferrie, J. E., Shipley, M., Marmot, M., Stansfeld, S., \& Davey Smith, G. (1995). Health effects of anticipation of job change and non-employment: longitudinal data from the Whitehall II study. British Medical Journal, 311(7015), 1264-1269.

Ferrie, J. E., Shipley, M. J., Marmot, M. G., Stansfeld, S., \& Smith, G. D. (1998a). The health effects of major organisational change and job insecurity. Social Science and Medicine, 46(2), 243-254.

Ferrie, J. E., Shipley, M. J., Marmot, M. G., Stansfeld, S. A., \& Smith, G. D. (1998b). An uncertain future: the health effects of threats to employment security in white-collar men and women. American Journal of Public Health, 88(7), 1030-1036.

Ferrie, J. E., Shipley, M. J., Stansfeld, S. A., \& Marmot, M. G. (2002). Effects of chronic job insecurity and change in job security on self reported health, minor psychiatric morbidity, physiological measures, and health related behaviours in British civil servants: the Whitehall II study. Journal of Epidemiology and Community Health, 56(6), 450-454.

Hamilton, V., Rroman, C., Hoffman, W., \& Renner, D. (1990). Hart times and vulnerable people: initial effects of plant closing on autoworkers' mental health. Journal of Health and Social Behavior, 31, 123-140.

Heaney, C., Israel, B., \& House, J. (1994). Chronic job insecurity among automobile workers: Effects on job satisfaction and health. Social Science and Medicine, 38(10), 1431-1437.

Hurrell, J. J., Jr., Nelson, D. L., \& Simmons, B. L. (1998). Measuring job stressors and strains: where we have been, 
where we are, and where we need to go. Journal of Occupational Health Psychology, 3(4), 368-389.

Jenkins, R., MacDonald, A., Murray, J., \& Strathdee, G. (1982). Minor psychiatric morbidity and the threat of redundancy in a professional group. Psychosomatic Medicine, 12, 799-807.

Joelson, L., \& Wahlquist, L. (1987). The psychological meaning of job insecurity and job loss: results of a longitudinal study. Social Science and Medicine, 25(2), 179-182.

Karasek, R., Baker, D., Marxer, F., Ahlbom, A., \& Theorell, T. (1981). Job decision latitude, job demands, and cardiovascular disease: a prospective study of Swedish men. American Journal of Public Health, 71(7), 694-705.

Karasek, R., Brisson, C., Kawakami, N., Houtman, I., Bongers, P., \& Amick, B. (1998). The Job Content Questionnaire (JCQ): an instrument for internationally comparative assessments of psychosocial job characteristics. Journal of Occupational Health Psychology, 3(4), 322-355.

Karasek, R., \& Theorell, T. (1990). Healthy work-stress, productivity, and the reconstruction of working life. New York: Basic Books.

Karasek, R. A., Theorell, T., Schwartz, J. E., Schnall, P. L., Pieper, C. F., \& Michela, J. L. (1988). Job characteristics in relation to the prevalence of myocardial infarction in the US Health Examination Survey (HES) and the Health and Nutrition Examination Survey (HANES). American Journal of Public Health, 78(8), 910-918.

Kivimaki, M., Vahtera, J., Ferrie, J. E., Hemingway, H., \& Pentti, J. (2001). Organisational downsizing and musculoskeletal problems in employees: a prospective study. Occupational \& Environmental Medicine, 58(12), 811-817.

Kivimaki, M., Vahtera, J., Pentti, J., \& Ferrie, J. E. (2000). Factors underlying the effect of organisational downsizing on health of employees: longitudinal cohort study. British Medical Journal, 320(7240), 971-975.

Kristensen, T. S., Borg, V., \& Hannerz, H. (2002). Socioeconomic status and psychosocial work environment: results from a Danish national study. Scandinavian Journal of Public Health, 59(Suppl), 41-48.
Lee, S., Colditz, G. A., Berkman, L. F., \& Kawachi, I. (2004). Prospective study of job insecurity and coronary heart disease in US women. Annals of Epidemiology, 14(1), 24-30.

Lerner, D., Levine, S., Malspeis, S., \& D'Agostino, R. (1994). Job strain and health-related quality of life in a national sample. American Journal of Public Health, 84, $1580-1585$.

Levi, L., Bartley, M., Marmot, M., Karasek, R., Theorell, T., Siegrist, J., et al. (2000). Stressors at the workplace: theoretical models. Occupational Medicine, 15(1), 69-106.

Mattiasson, I., Lindgarde, F., Nilsson, J. A., \& Theorell, T. (1990). Threat of unemployment and cardiovascular risk factors: longitudinal study of quality of sleep and serum cholesterol concentrations in men threatened with redundancy. British Medical Journal, 301(6750), 461-466.

McDonough, P. (2000). Job insecurity and health. International Journal of Health Services, 30(3), 453-476.

McNutt, L. A., Wu, C., Xue, X., \& Hafner, J. P. (2003). Estimating the relative risk in cohort studies and clinical trails of common outcomes. American Journal of Epidemiology, 157(10), 940-943.

Morris, J., Cook, D., \& Shaper, A. (1994). Loss of employment and mortality. British Medical Journal, 308, 1135-1139.

Probst, T. M. (2000). Wedded to the job: moderating effects of job involvement on the consequences of job insecurity. Journal of Occupational Health Psychology, 5(1), 63-73.

Probst, T. M. (2002). Layoffs and tradeoffs: production, quality, and safety demands under the threat of job loss. Journal of Occupational Health Psychology, 7(3), 211-220.

Probst, T. M., \& Brubaker, T. L. (2001). The effects of job insecurity on employee safety outcomes: cross-sectional and longitudinal explorations. Journal of Occupational Health Psychology, 6(2), 139-159.

Schnall, P. L., Landsbergis, P. A., \& Baker, D. (1994). Job strain and cardiovascular disease. Annual Review of Public Health, 15, 381-411.

Ware, J., Snow, K., Kosinski, M., \& Gandek, B. (1993). SF-36 Health Survey: Manual and Interpretation Guide. Boston, MA: New England Medical Center, The Health Institute. 